\title{
Pengembalian Kerugian Nasabah Akibat Penggelapan Pihak Bank Dengan Penjatuhan Pidana
}

\author{
Anna Maria Salamor ${ }^{1 *}$, Elias Zadrack Leasa ${ }^{2}$, Harun Matayane $^{3}$ \\ 1,2,3 Fakultas Hukum Universitas Pattimura, Ambon \\ annamariasalamor@gmail.com ${ }^{1}$; eliaszleasa72@gmail.com ${ }^{2}$; harunmatayane@gmail.com³ $^{3}$ \\ * Corespondence Author
}

\begin{abstract}
Abstrak
Penggelapan oleh oknum Bank mengakibatkan kerugian yang muncul, dan setelah putusan pengadilan tidak menimbulkan rasa keadilan bagi korban. Tujuan penulisan ini untuk menemukan bagaimana pengembalian kerugian korban dengan putusan pidana. Metode yuridis normatif. Tindak Pidana di Dunia Perbankan salah satunya adalah penggelapan, kasus penggelapan seringkali tidak berujung pada rasa keadilan korban, karena putusan pidana tidak membebankan ganti rugi, padahal akibat perbuatan terdakwa, ada korban yang mengalami kerugian. Kerugian korban tindak pidana penggelapan oleh oknum Bank dapat memperoleh keadilan atas ganti rugi sebagaima Putusan Mahkamah Konstitusi Nomor 81/PUU-XVII/2019 dan Pasal 96 sampai dengan Pasal 99 Kitab Undang-Undang Hukum Acara Pidana.
\end{abstract}

\section{Kata Kunci : Penggelapan, Keadilan, Pengembalian Kerugian}

Naskah dikirim: 27 Desember 2020|Direvisi: 15 Februari 2021|Diterbitkan: 28 Februari 2021 


\begin{abstract}
Embezzlement by unscrupulous bankers resulted in losses that appeared, and after the court decision did not cause a sense of justice for the victim. The purpose of this writing is to find out how to recover the victim's loss with a criminal verdict. Normative juridical methods. One of the criminal acts in the banking sector is embezzlement, cases of embezzlement often do not lead to a sense of justice for the victim, because the criminal verdict does not impose compensation, even though as a result of the defendant's act, a victim suffered losses. Losses for victims of criminal acts of embezzlement by unscrupulous banks can obtain justice for damages as the Constitutional Court Decision Number 81 / PUU-XVII / 2019 and Articles 96 to Article 99 of the Criminal Procedure Code.
\end{abstract}

\title{
Keywords: Embezzlement, Justice, Returns of Losses
}

\section{Pendahuluan}

Berbagai kebijakan pengelolaan keuangan masyarakat, ada masyarakat yang menginvestasikan, ada juga yang memilih menabung di bank, ada yang memakai tabungan asuransi dan masih banyak lagi cara masyarakat mengelola keuangan mereka, dalam perkembangannya pihak Bank berupaya untuk melakukan pengamanan berlapis dalam pengelolaan Bank, karena akan berhubungan dengan kepercayaan nasabah bahwa bank tersebut aman, baik acaman kejahatan dari pihak luar maupun dari pihak dalam bank sendiri.

Pratywi Precilia Soraya, mengatakan bahwa Tindak pidana perbankan pada umumnya dapat terjadi dengan berbagai cara atau modus. Sejalan dengan perkembangan kemajuan ilmu pengetahuan dan teknologi, maka tidak dapat disangkal pula bermunculannya modus baru di bidang kejahatan perbankan sehingga dikenal berbagai 
macam kejahatan perbankan di dunia dan di Indonesia pada khususnya. Semakin maraknya kejahatan perbankan yang terjadi saat ini, mengakibatkan perlunya penguatan atas segala upaya untuk mencegah serta memberantas kejahatan perbankan tersebut. Pengawasan pun menjadi salah satu alternatifnya. Tindakan pengawasan terhadap bank ini pun dipandang sangat penting guna memelihara kepercayaan masyarakat (nasabah) terhadap bank itu sendiri serta agar dapat mencapai dan memelihara kestabilan nilai rupiah, seperti yang menjadi tujuan dari Bank Indonesia. Bentuk pengawasan yaitu pengawasan eksternal, pengawasan internal dan pengawasan masyarakat. Apabila berjalan secara efektif dipastikan kejahatan perbankan dapat diminimalkan dan tidak lagi mewarnai industri perbankan. ${ }^{1}$

Pihak bank sendiri biasa tidak langsung memposes hukum, namun diselesaikan dulu secara internal Bank, seperti kasus Atlet Game Online WL yang kemudian kehilanggan tabungannya sebesar Rp. 20.000.000.000 (dua puluh milyar rupiah), namun jika korban sudah melaporkan ke Pihak Kepolisian maka akan menjadi masalah karena akan dilakukan penyelidikan dan penyidikan terhadap kasus tersebut, atau kasus pembobolan Bank BNI Cabang Ambon, sedangkan pada penulisan ini penulis mengambil akan membahas kasus penipuan dalam Putusan Nomor: 341/Pid.B/2018/PN.Amb.

Dalam putusan tindak pidana di bidang perbankan seringkali yang dirugikan adalah korban, untuk itu dalam penulisan ini akan membahas bagaimana memberikan keadilan kepada korban dengan mekanisme hukum pidana materiil yang dihubungkan dengan hukum pidana formil. Penegakan hukum harus diarahkan bukan saja mewujudkan kepastian hukum namun juga keadilian. ${ }^{2}$ Hal korban harus diperhatikan bukans aja hak dari terdakwa dan tersangka dalam penegakan hukum.

1 Pratywi Precilia Soraya (2013). PENCEGAHAN DAN PEMBERANTASAN KEJAHATAN PERBANKAN MELALUI SARANA PENGAWASAN. Lex Crimen Vol. II/No. 2/Apr-Jun/2013, 87-97

2Erwin Ubwarin, (2019), Penegakan Hukum Terhadap Pelaku Penyelundupan Penyu Di Kabupaten Kepulauan Aru, RESAM Jurnal Hukum, 5 (1), DOI: https://doi.org/10.32661/resam.v5i1.15, 1-20

DOI: https://doi.org/10.30598/belovol6issue2page208-220 


\section{Pembahasan}

Tindak pidana penggelapan diatur dalam Pasal 372, Pasal 374, dan Pasal 375 KUHPidana. Pasal 376 mengatur mengenai penggelapan antar keluarga yang berlaku sama dengan Pasal 367 KUHPidana (delik pencurian). Selanjutnya Pasal 377 KUHPidana mengenai pidana tambahan berupa pengumuman putusan hakim dan pencabutan hak dapat dikenakan bagi penggelapan Pasal 372, Pasal 374, dan Pasal 375 KUHPidana.

Pengertian Tindak Pidana Penggelapan diatur dalam Pasal 372 KUHP. Pasal 372 KUHP yang berbunyi Barang siapa dengan sengaja memiliki dengan melawan hak suatu benda yang sama sekali atau sebahagiannya termasuk kepunyaan orang lain dan benda itu ada dalam tangannya bukan karena kejahatan, dihukum karena penggelapan, dengan hukuman penjara selama-lamanya empat tahun atau denda sebanyak Rp. $900 .^{3}$ Inti delik atau tindak pidana penggelapan sebagaimana diatur dalam Pasal 372 KUHPidana adalah sebagai berikut: Pertama, Sengaja: Kedua, Melawan hukum; Ketiga, Memiliki suatu barang; Keempat, Yang seluruhnya atau kepunyaan orang lain; Kelima, Yang ada dalam kekuasaannya bukan karena kejahatan. ${ }^{4}$

Ketentuan Pasal 373 Kitab Undang-Undang Hukum Pidana (KUHP) mengatur delik penggelapan ringan jika barang itu bukan ternak dan nilainya tidak lebih dari dua ratus lima puluh rupiah. Suatu jumlah yang sudah tidak sesuai dengan zamannya. Sementara ketentuan Pasal 374 KUHP mengatur tentang delik kualifikasi, artinya suatu delik suatu penggelapan Pasal 372 KUHP sebagai delik pokok, ditambah satu bagian inti delik lagi yakni dilakukan karena ada hubungan kerja atau karena pencahariannya atau karena mendapat upah, ancaman pidananya bertambah dari empat tahun penjara menjadi lima tahun penjara. Kemudian Pasal 375 KUHP mengatur bagian inti sama dengan delik pokok (Pasal 372 KUHPidana) ditambah bagian inti delik dilakukan oleh orang yang

\footnotetext{
${ }^{3}$ Soesilo, R, 1994, Kitab Undang-undang Hukum Pidana serta Komentar-komentarnya Lengkap Pasal demi Pasal, Politea, Bogor.

${ }^{4}$ Hamzah, Andi, 2009, Delik-DelikTertentu (Speciale Delicten) DiDalam KUHP.Sinar Grafika. Jakarta
}

DOI: https://doi.org/10.30598/belovol6issue2page208-220 
karena terpaksa diberi barang untuk disimpan, atau dilakukan oleh pengampu, pengurus atau pelaksana surat wasiat, pengurus lembaga atau yayasan terhadap barang yang dikuasainya selaku demikian. Berikutnya Pasal 376 KUHP menyatakan bahwa ketentuan tentang pencurian antarkeluarga (Pasal 367 KUHP) berlaku juga bagi delik penggelapan. ${ }^{5}$

Muljatno mengatakan, hukum pidana memberikan dasar-dasar dan aturan-aturan untuk:

1. Menentukan perbuatan-perbuatan mana yang tidak boleh dilakukan, yang dilarang dengan disertai ancaman atau sanksi berupa pidana tertentu bagi barang siapa melanggar larangan tersebut.

2. Menentukan kapan dan dalam hal-hal apa kepada mereka yang telah melanggar larangan itu dapat dikenakan atau dijatuhi pidana sebagaimana telah diancamkan

3. Menentukan dengan cara bagaimana pengenaan pidana itu dapat dilaksanakan apabila ada orang yang disangka telah melanggar larangan tersebut. ${ }^{6}$

Muljatno pengertian tersebut dikelompokkan menjadi hukum pidana materiil (substantif criminal law), yaitu semua peraturan yang mengenai bidang nomor 1 dan nomor 2, serta hukum pidana formil (hukum acara pidana) untuk peraturan yang mengenai nomor 3 . $^{7}$

Adanya dua sisi dalam hukum pidana, yaitu sisi yang mengatur tentang aturan perbuatan-perbuatan tertentu yang dilarang serta orang yang melanggar larangan tersebut, dan ancaman pidananya, disebut dengan hukum pidana substantif atau hukum pidana materiil. Sementara disisi yang lain mengatur tentang bagaimana negara yang memiliki hak

5 Daud Rahim, (2012), PERTANGGUNGJAWABAN PIDANA PENGGELAPAN DALAM PERJANJIAN KREDIT (STUDI KASUS PERJANJIAN KREDIT SEPEDA MOTOR), Jurnal Legalitas, Vol 5 No. 1, DOI: https://doi.org/10.33756/jelta.v5i01.881, 1-13

${ }_{7}^{6}$ Mulyatno, 2013, Asas-asas Hukum Pidana, Yogyakarta : Gajah Mada University Press, hal 1

7 Ibid.hal 12

DOI: https://doi.org/10.30598/belovol6issue2page208-220 
dalam melaksanakan proses peradilan untuk menjalankan penuntutan, mengadili dan melaksanakan pidana terhadap orang yang bersalah, disebut dengan hukum pidana formil. ${ }^{8}$

Dalam perkara No : 341/Pid.B/2018/PN.Amb, hukum pidana materiil mengenai aset tindak pidana diatur dalam Pasal 39 KUHP, 1) Barang-barang kepunyaan terpidana yang diperoleh dari kejahatan atau yang sengaja dipergunakan untuk melakukan kejahatan, dapat dirampas; 2) Dalam hal pemidanaan karena kejahatan yang tidak dilakukan dengan sengaja atau karena pelanggaran, dapat juga dijatuhkan putusan perampasan berdasarkan hal-hal yang ditentukan dalam undang-undang; 3) Perampasan dapat dilakukan terhadap orang yang bersalah yang diserahkan kepada pemerintah, tetapi hanya atas barang-barang yang telah disita; dan hukum pidana formil diatur dalam Pasal 46 KUHAP, 1) Benda yang dikenakan penyitaan dikembalikan kepada orang atau kepada mereka dan siapa benda itu disita, atau kepada orang atau kepada mereka yang paling berhak apabila: a. kepentingan penyidikan dan penuntutan tidak memerlukan lagi; b. perkara tersebut tidak jadi dituntut karena tidak cukup bukti atau ternyata tidak merupakan tindak pidana; c. perkara tersebut dikesampingkan untuk kepentingan umum atau perkara tersebut ditutup demi hukum, kecuali apabila benda itu diperoleh dan suatu tindak pidana atau yang dipergunakan untuk melakukan suatu tindak pidana. 2) Apabila perkara sudah diputus, maka benda yang dikenakan penyitaan dikembalikan kepada orang atau kepada mereka yang disebut dalam putusan tersebut kecuali jika menurut putusan hakim benda itu dirampas untuk negara, untuk dimusnahkan atau untuk dirusakkan sampai tidak dapat dipergunakan lagi atau jika benda tersebut masih diperlukan sebagai barang bukti dalam perkara lain.

Putusan Mahkamah Konstitusi Nomor 81/PUU-XVII/2019, muncul karena para penggugat mencontohkan Kasus PT. First Anugerah Karya Wisata atau First Travel yang tidak dikembalikan kepada jemaah yang menjadi korban kasus penipuan umrah, padahal barang bukti yang disita dalam kasus tersebut adalah benda-benda yang diperoleh berdasarkan hasil tindak pidana. Mahkamah merumuskan Pasal 39 KUHP dan Pasal 46

\footnotetext{
${ }^{8}$ I Ketut Mertha dkk, 2016, Buku Ajar Hukum Pidana, Universitas Udayana, hal 45
}

DOI: https://doi.org/10.30598/belovol6issue2page208-220 Copyright (c) 2021 Author 
KUHAP. Kasus First Travel dalam Putusan Kasasi Nomor 3096 K/Pid.Sus/2018, disebutkan "Bahwa sebagaimana fakta di persidangan, barang-barang bukti tersebut merupakan hasil kejahatan yang dilakukan oleh para Terdakwa dan disita dari para Terdakwa yang telah terbukti selain melakukan tindak pidana Penipuan juga terbukti melakukan tindak pidana Pencucian Uang. Oleh karenanya berdasarkan ketentuan Pasal 39 KUHP juncto Pasal 46 KUHAP barang-barang bukti tersebut dirampas untuk Negara.

Putusan Mahkamah Konstitusi Nomor 81/PUU-XVII/2019 menambahkan penjelasan atas Pasal 39 KUHP juncto Pasal 46 KUHAP, yaitu :

Amar putusan point ke 2 dan point ke 3 :

a. Menyatakan Pasal 39 KUHP dan Pasal 46 KUHAP sepanjang kalimat, Pasal 39 KUHP berbunyi: (1) Barang-barang kepunyaan terpidana yang diperoleh dari kejahatan atau yang sengaja dipergunakan untuk melakukan kejahatan, dapat dirampas. (2) Dalam hal pemidanaan karena kejahatan yang tidak dilakukan dengan sengaja atau karena pelanggaran, dapat juga dijatuhkan putusan perampasan berdasarkan hal-hal yang ditentukan dalam undangundang. (3) Perampasan dapat dilakukan terhadap orang yang bersalah yang diserahkan kepada pemerintah, tetapi hanya atas barang-barang yang telah disita; dan Pasal 46 KUHAP berbunyi: (1) Benda yang dikenakan penyitaan dikembalikan kepada orang atau kepada mereka dan siapa benda itu disita, atau kepada orang atau kepada mereka yang paling berhak apabila: a. kepentingan penyidikan dan penuntutan tidak memerlukan lagi; b. perkara tersebut tidak jadi dituntut karena tidak cukup bukti atau ternyata tidak merupakan tindak pidana; c. perkara tersebut dikesampingkan untuk kepentingan umum atau perkara tersebut ditutup demi hukum, kecuali apabila benda itu diperoleh dan suatu tindak pidana atau yang dipergunakan untuk melakukan suatu tindak pidana. (2) Apabila perkara sudah diputus, maka benda yang dikenakan penyitaan dikembalikan kepada orang atau kepada mereka yang disebut dalam putusan tersebut kecuali jika menurut putusan hakim benda itu dirampas untuk 
negara, untuk dimusnahkan atau untuk dirusakkan sampai tidak dapat dipergunakan lagi atau jika benda tersebut masih diperlukan sebagai barang bukti dalam perkara lain. bertentangan dengan Undang-Undang Dasar Negara Republik Indonesia Tahun 1945 secara bersyarat (conditionally unconstitutional) kecuali dimaknai sebagai 7 berikut: "Pasal 39 KUHP berbunyi: (1) Barang-barang kepunyaan terpidana yang diperoleh dari kejahatan atau yang sengaja dipergunakan untuk melakukan kejahatan, dapat dirampas dan dikembalikan kepada Korban; (2) Dalam hal pemidanaan karena kejahatan yang tidak dilakukan dengan sengaja atau karena pelanggaran, dapat juga dijatuhkan putusan perampasan berdasarkan hal-hal yang ditentukan dalam undang-undang untuk mengganti kerugian korban tindak pidana; (3) Perampasan dapat dilakukan terhadap orang yang bersalah yang diserahkan kepada Pemerintah untuk kepentingan publik, tetapi hanya atas barang-barang yang telah disita dari kerugian Negara;

Pasal 46 KUHAP berbunyi: (1) Benda yang dikenakan penyitaan dikembalikan kepada orang atau kepada mereka dan siapa benda itu disita, atau kepada orang atau kepada mereka yang dirugikan akibat tindak pidana dan atau yang paling berhak apabila: a. kepentingan penyidikan dan penuntutan tidak memerlukan lagi; b. perkara tersebut tidak jadi dituntut karena tidak cukup bukti atau ternyata tidak merupakan tindak pidana; c. perkara tersebut dikesampingkan untuk kepentingan umum atau perkara tersebut ditutup demi hukum, kecuali apabila benda itu diperoleh dan suatu tindak pidana atau yang dipergunakan untuk melakukan suatu tindak pidana. (2) Apabila perkara sudah diputus, maka benda yang dikenakan penyitaan dikembalikan kepada orang atau kepada mereka yang disebut dalam putusan tersebut kecuali jika menurut putusan hakim benda itu dirampas untuk

Negara setelah mendapat persetujuan dari korban tindak pidana, untuk dimusnahkan atau untuk dirusakkan sampai tidak dapat dipergunakan lagi atau jika benda tersebut masih diperlukan sebagai barang bukti dalam perkara lain;

b. Menyatakan Pasal 39 KUHP dan Pasal 46 KUHAP mempunyai kekuatan hukum mengikat dengan persyaratan bahwa sepanjang frasa "Pasal 39 KUHP berbunyi: 
(1) Barang-barang kepunyaan terpidana yang diperoleh dari kejahatan atau yang sengaja dipergunakan untuk melakukan kejahatan, dapat dirampas dan dikembalikan kepada Korban; (2) Dalam hal pemidanaan karena kejahatan yang tidak dilakukan dengan sengaja atau karena pelanggaran, dapat juga dijatuhkan putusan perampasan berdasarkan hal-hal yang ditentukan dalam undang-undang untuk mengganti kerugian korban tindak pidana; (3) Perampasan dapat dilakukan terhadap orang yang bersalah yang diserahkan kepada Pemerintah untuk kepentingan publik, tetapi hanya atas barang-barang yang telah disita dari kerugian Negara;

Pasal 46 KUHAP berbunyi: (1) Benda yang dikenakan penyitaan dikembalikan kepada orang atau kepada mereka dan siapa benda itu disita, atau kepada orang atau kepada mereka yang dirugikan akibat tindak pidana dan atau yang paling berhak apabila: a. kepentingan penyidikan dan penuntutan tidak memerlukan lagi; b. perkara tersebut tidak jadi dituntut karena tidak cukup bukti atau ternyata tidak merupakan tindak pidana; c. perkara tersebut dikesampingkan untuk kepentingan umum atau perkara tersebut ditutup demi hukum, kecuali apabila benda itu diperoleh dan suatu tindak pidana atau yang dipergunakan untuk melakukan suatu tindak pidana. (2) Apabila perkara sudah diputus, maka benda yang dikenakan penyitaan dikembalikan kepada orang atau kepada mereka yang disebut dalam putusan tersebut kecuali jika menurut putusan hakim benda itu dirampas untuk Negara setelah mendapat persetujuan dari korban tindak pidana, untuk dimusnahkan atau untuk dirusakkan sampai tidak dapat dipergunakan lagi atau jika benda tersebut masih diperlukan sebagai barang bukti dalam perkara lain;

Dalam Putusan Nomor: 341/Pid.B/2018/PN.Amb. amar putusannya menyebutkan :

1. Menyatakan terdakwa AIL alias IBU AS tersebut di atas, terbukti secara sah dan meyakinkan bersalah melakukan tindak pidana "PENGGELAPAN DALAM JABATAN SECARA BERLANJUT", sebagaimana dakwaan kesatu;

2. Menjatuhkan pidana kepada terdakwa AIL alias IBU AS oleh karena itu dengan pidana penjara selama 4 (empat) tahun; 
3. Menetapkan masa penangkapan dan penahanan yang telah dijalani terdakwa dikurangkan seluruhnya dari pidana yang dijatuhkan; Menetapkan terdakwa tetap ditahan;

4. Menetapkan terdakwa tetap ditahan ;

5. Semua Assetnya tindak pidana dikembalikan kepada BRI.

6. Membebankan kepada terdakwa untuk membayar biaya perkara masing-masing sebesar Rp. 2.000,- (dua ribu rupiah);

Perlindungan hukum adalah bentuk dari mewujudkan keadilan bagi korban, ${ }^{9}$

Menurut penulis, selain menggunakan Putusan Mahkamah Konstitusi Nomor 81/PUU-

XVII/2019, dapat juga memakai jalur perdata dan penetapan dalam putusan dalam jalur

pidana dengan dasar hukum : ${ }^{10}$

Bahwa Pasal 96 ayat (1) KUHAP: Putusan pemberian ganti kerugian berbentuk penetapan.

Bahwa Pasal 96 ayat (2) KUHAP: Penetapan sebagaimana yang di maksud dalam ayat (1) memuat dengan lengkap semua hal yang dipertimbangkan sebagai alasan bagi putusan tersebut.

Bahwa Pasal 98 ayat (1) KUHAP: Jika suatu perbuatan yang menjadi dasar dakwaan di dalam suatu pemeriksaaan perkara pidana oleh pengadilan negeri menimbulkan kerugian bagi orang lain, maka hakim ketua sidang atas permintaan orang itu dapat menetapkan untuk menggabungkan perkara gugatan ganti rugi kepada perkara pidana itu.

Bahwa Pasal 98 ayat (2) KUHAP: Permintaan sebagaimana dimaksud dalam ayat (1) hanya dapat dilakukan selambat-lambatnya sebelum penuntut umum mengajukan tuntutan pidana dalam hal penuntut umum tidak hadir; permintaan diajukan selambat- lambatnya sebelum hakim mengajukan putusan.

Bahwa Pasal 99 ayat (1) KUHAP: Apabila pihak yang dirugikan minta penggabungan perkara gugatannya pada perkara pidana sebagaimana dimaksud dalam pasal 98, maka pengadilam negeri menimbang tentang kewenangannya

\footnotetext{
${ }^{9}$ Fadillah, A. (2019). Perlindungan Hukum Terhadap Anak Yang Menjadi Korban Aksi Perundungan. JURNAL BELO, 5(1), 86-100. DOI : https://doi.org/10.30598/belovol5issuelpage86-100.

${ }^{10}$ Butje, Tampi (2014), KUHAP DAN PENGATURAN GANTI RUGI PIHAK KORBAN DALAM PERADILAN PIDANA. Jurnal Hukum Unsrat , II (2). 24-35
}

DOI: https://doi.org/10.30598/belovol6issue2page208-220 
umum mengadili gugatan tentang kebenaran dasar gugatan dan tentang hukuman penggantian biaya yang telah dikeluarkan oleh pihak yang dirugikan tersebut.

Bahwa Pasal 99 ayat (2) KUHAP: Kecuali dalam hal pengadilan negeri menyatakan tidak berwenang mengadili gugatan sebagaimana dimaksud dalam ayat (1) atau gugatan dinyatakan tidak dapat diterima, putusan hakim hanya memuat penetapan hukuman penggantian biaya yang telah dikeluarkan oleh pihak yang dirugikan.

Bahwa Pasal 99 ayat (3) KUHAP: Putusan mengenai ganti kerugian dengan sendirinya mendapat kekuatan tetap, apabila putusan pidananya juga mendapat kekuatan hukum yang tetap.

Putusan pengadilan harusnya memberikan kepastian hukum dan keadilan bagi korban, jika melihat penjelasan diatas tentang Putusan Mahkamah Konstitusi Nomor 81/PUU-XVII/2019 dan Pasal 96 sampai dengan Pasal 99 KUHAP, jika Jaksa Penuntut Umum dan Hakim melakukan ganti rugi dengan penetapan putusan pengadilan pidana, maka akan muncul keadilan bagi korban penggelapan yang dilakukan oleh oknum pihak bank. Bentuk putusan yang melindungi korban dengan melakukan ganti rugi adalah bentuk perlindungan hukum kepada korban, karena tujuan hukum salah satunya adalah memberikan rasa keadilan bagi pencari keadilan, untuk itu pengadilan harus memberikan putusan yang memberi keadilan bagi korban. ${ }^{11}$

\section{Penutup}

Tindak Pidana di Dunia Perbankan salah satunya adalah penggelapan, kasus penggelapan seringkali tidak berujung pada rasa keadilan korban, karena putusan pidana tidak membebankan ganti rugi, padahal akibat perbuatan terdakwa, ada korban yang mengalami kerugian. Kerugian korban tindak pidana penggelapan oleh oknum Bank dapat memperoleh keadilan atas ganti rugi sebagaima Putusan Mahkamah Konstitusi Nomor 81/PUU-XVII/2019 dan Pasal 96 sampai dengan Pasal 99 Kitab Undang-Undang Hukum Acara Pidana.

${ }^{11}$ Wadjo, H., \& Saimima, J. (2020). Perlindungan Hukum Terhadap Korban Kekerasan Seksual Dalam Rangka Mewujudkan Keadilan Restoratif. JURNAL BELO, 6(1), DOI: https://doi.org/10.30598/belovol6issue1page48-59

DOI: https://doi.org/10.30598/belovol6issue2page208-220 Copyright (c) 2021 Author 


\section{Daftar Pustaka}

\section{Jurnal}

[1] Butje, Tampi (2014), KUHAP DAN PENGATURAN GANTI RUGI PIHAK KORBAN DALAM PERADILAN PIDANA. Jurnal Hukum Unsrat , II (2).

[2] Daud Rahim, (2012), PERTANGGUNGJAWABAN PIDANA PENGGELAPAN DALAM PERJANJIAN KREDIT (STUDI KASUS PERJANJIAN KREDIT SEPEDA MOTOR), Jurnal Legalitas, Vol 5 No. 1, DOI: https://doi.org/10.33756/jelta.v5i01.881

[3] Erwin Ubwarin, (2019), Penegakan Hukum Terhadap Pelaku Penyelundupan Penyu Di Kabupaten Kepulauan Aru, RESAM Jurnal Hukum, 5 (1), DOI: https://doi.org/10.32661/resam.v5i1.15

[4] Fadillah, A. (2019). Perlindungan Hukum Terhadap Anak Yang Menjadi Korban Aksi Perundungan. JURNAL BELO, 5(1), 86-100. DOI : https://doi.org/10.30598/belovol5issue1page86-100

[5] Pratywi Precilia Soraya (2013). PENCEGAHAN DAN PEMBERANTASAN KEJAHATAN PERBANKAN MELALUI SARANA PENGAWASAN. Lex Crimen Vol. II/No. 2/Apr-Jun/2013, 87-97

[6] Wadjo, H., \& Saimima, J. (2020). Perlindungan Hukum Terhadap Korban Kekerasan Seksual Dalam Rangka Mewujudkan Keadilan Restoratif. JURNAL BELO, 6(1), DOI: https://doi.org/10.30598/belovol6issue1page48-59

\section{Buku}

[7] Hamzah, Andi, 2009, Delik-DelikTertentu (SpecialeDelicten) DiDalam KUHP.SinarGrafika. Jakarta

[8] I Ketut Mertha dkk, 2016, Buku Ajar Hukum Pidana, Universitas Udayana.

[9] Mulyatno, 2013, Asas-asas Hukum Pidana, Yogyakarta : Gajah Mada University Press. 
[10] Soesilo, R, 1994, Kitab Undang-undang Hukum Pidana serta Komentarkomentarnya Lengkap Pasal demi Pasal, Politea, Bogor. 